\title{
Evaluating the Behaviour of Chinese Stakeholders Engaged in Large Hydropower Projects in Asia and Africa
}

\author{
May Tan-Mullins ${ }^{*}$, Frauke Urban ${ }^{\dagger}$ and Grace Mang*
}

\begin{abstract}
Hydropower dams are back in the spotlight owing to a shifting preference for low carbon energy generation and their possible contribution to mitigating climate change. At the forefront of the renaissance of large hydropower dams are Chinese companies, as the builders of the world's largest dams at home and abroad, opening up opportunities for low- and middle-income countries. However, large hydropower dams, despite their possible developmental and carbon reduction contributions, are accompanied by huge economic costs, profound negative environmental changes and social impacts. Using fieldwork data from four hydropower projects in Ghana, Nigeria, Cambodia and Malaysia, this paper evaluates the behaviour of Chinese stakeholders engaged in large hydropower projects in Asia and Africa. We do this by first exploring the interests of the different Chinese stakeholders and then by investigating the wider implications of these Chinese dams on the local, national and international contexts. The paper concludes that hydropower dams will continue to play a prominent role in future efforts to increase energy security and reduce energy poverty worldwide, therefore the planning, building and mitigation strategies need to be implemented in a more sustainable way that takes into account national development priorities, the needs of local people and the impacts on natural habitats.
\end{abstract}

Keywords: China; Africa; Asia; hydropower; development; socioenvironment

The recently concluded COP21 climate change conference in Paris saw the adoption by 195 countries of the Paris Agreement, which acknowledged the "need to promote universal access to sustainable energy in developing countries."1

* University of Nottingham Ningbo China. Email: may.tan-mullins@nottingham.edu.cn (corresponding author).

$\dagger$ SOAS University of London.

+ International Rivers, China.

1 UNFCCC 2015. 
Supported by international organizations such as the International Renewable Energy Agency (IRENA), hydropower has been promoted as a clean and green source of energy at COP21, and several countries, France among them, announced that they would spend $€ 2$ billion in Africa on renewable energy generation including hydropower projects. ${ }^{2}$

In the face of an increasing world population and the accompanying rising demand for energy, building large hydropower dams has become an attractive policy solution to fuel development. According to an official at the International Energy Agency (IEA) in Paris, hydropower is viewed positively as one of the mitigation strategies for climate change at a global level. ${ }^{3}$ Other benefits include flood control, technological progress and job creation. ${ }^{4}$ However, large hydropower dams, despite their possible developmental and carbon reduction contribution, are accompanied by huge economic cost,${ }^{5}$ profound negative environmental changes, ${ }^{6}$ and social issues. ${ }^{7}$

As the builders of the world's largest dams, Chinese companies and financiers are at the forefront of the renaissance of large hydropower dams. ${ }^{8}$ China houses half of the world's 80,000 dams, ${ }^{9}$ and Chinese firms have the mature technology and expertise in the field of dam construction that allow them to build dams at lower cost than their Western competitors. ${ }^{10}$ However, these hydropower dam builders are having to look overseas for new projects because of such reasons as the Chinese government's "going out" strategy, increasing domestic competition, and the declining number of suitable sites for new dams within Chinese borders, to name but a few. These overseas hydropower projects can be tied in with Chinese government aid, preferential loans and resources repayment, and almost always correlate with increasing trade and investment levels in the receiving countries. The majority of new dam projects have been proposed in South-East Asia (141) and Africa (94), and more recently in Latin America (23). ${ }^{11}$ Sinohydro, also known as PowerChina, a Chinese state-owned enterprise (SOE), is the leading global hydropower firm in terms of the number and size of dams built, investment sums and global coverage. ${ }^{12}$ It completed its first large hydropower project in 2003 and is now associated with over 122 international projects. ${ }^{13}$

2 "COP21: France to spend billions on African renewable energy projects," The Guardian, 1 December 2015, http://www.theguardian.com/environment/2015/dec/01/cop21-france-to-spend-billions-on-africanrenewable-energy-projects. Accessed 1 March 2016.

3 Interviews with IEA representative, Paris, 23 June 2015.

4 Billington and Jackson 2006.

5 World Commission on Dams 2000; Ansar et al. 2014; Sovacool, Nugent and Gilbert 2014.

6 Brown et al. 2009

7 Sovacool and Bulan 2011; McDonald-Wilmsen and Webber 2010.

8 Urban et al. 2015 b.

9 Walker and Qin 2015.

10 Interview with Sinohydro representative, Beijing, May 2015.

11 International Rivers 2012.

12 Urban et al. 2015b.

13 Bosshard 2014. 
Many factors contribute to the "successful" building and long-term management of a mega hydropower project, ranging from rigorous environmental impact assessments (EIA), best-practice engineering, fair resettlement procedures and just compensation, to thorough environmental mitigation strategies such as grievance and complaints mechanisms, corporate social responsibilities (CSR) and attention to social and local cultural practices. In addition, the host country's agencies and regulatory framework also play a vital role in determining the immediate outcomes and long-term implications of these Chinese hydropower projects. However, this paper moves away from host country regulatory frameworks and instead aims to address the role of Chinese actors in the global hydropower industry. This is because there is a greater need to deconstruct the Chinese hydropower sector, in terms of the motives of different actors, the types of contracts agreed and how they are negotiated, and how the impacts are managed and mitigated by Chinese companies. It is only through understanding what drives the Chinese actors and how these processes work that we will be able to engage these Chinese stakeholders to better manage and mitigate the impacts of mega development projects.

This paper aims to investigate what shapes the behaviour of Chinese stakeholders engaged in large hydropower projects in Asia and Africa. In addition to stakeholder mapping and Nvivo data analysis, we use empirical data from four case studies in Asia (the Kamchay Dam in Cambodia and the Bakun Dam in Malaysia) and Africa (the Bui Dam in Ghana and the Zamfara Dam in Nigeria), and interviews conducted in China, to triangulate information on the Chinese hydropower industry. We aim to gain a better understanding of the motives of these actors, the decision-making processes in the implementation and mitigation phases, and their power relations in conjunction with each other. The analysis of the data is largely guided by a political ecology conceptual framework.

The remainder of this paper is organized as follows. The next section discusses the conceptual framework and methodology. This is followed by an examination of the motives of various actors. The paper continues with an assessment of the different modalities and the negotiation process for these projects, and then investigates the ways in which Chinese stakeholders mitigate the impacts of these overseas hydropower dams. It concludes with an assessment of the sustainability of these mega projects, contributions to the theoretical framework and policy implications of these findings.

\section{Conceptual Framework and Methodology: Political Ecology of Chinese Hydropower Dams}

The political ecology framework ${ }^{14}$ is used as a basis for analysing the implications caused by the varied forms of control over the access to natural resources such as water, fisheries and energy to highlight governance issues and the unequal 
distribution of costs and benefits associated with environmental change brought by human intervention. ${ }^{15}$ "It is an integrated understanding of how environmental and political forces interact to mediate social and environmental change."16 The power relations between different actors are at the heart of the political ecology framework, and power is conceptualized by the ability to control access to valued environmental resources, the main objective of which is control and/or access to the economic benefits ensuing from resource exploitation. ${ }^{17}$ Different resources such as knowledge and technology as well as access to information empower different actors to varying degrees to effect change on the environment.

Large-scale dam development provokes strong emotions because of the uneven distribution of costs and benefits, which in turn focuses attention on the political environment and the actors involved. It is therefore vital to investigate actors' interests and how these interests determine the behaviour of actors operating at the national and international level, and how they might influence the locals' interaction with the resources. A key advantage of this approach is that it allows for a more complex understanding of the interactions between these actors. ${ }^{18}$ However, this approach tends to treat the actors (such as businesses) as monolithic entities. ${ }^{19}$ This becomes problematic when assessing the power relations between stakeholders in an industry, the host-state agencies vis-à-vis transnational businesses, as the footlessness of these latter actors enables them to be less constrained by the regulatory power held by host governments. This paper fills this gap by deconstructing the Chinese hydropower sector by examining where the actual power lies among the various actors involved, and what empowers these actors.

When we refer to sustainability in relation to hydropower developments, we refer to the environmental, social and economic dimensions of sustainable development. We use the Brundtland Report's definition of sustainable development, which is "development that meets the needs of the present without compromising the ability of future generations to meet their own needs." ${ }^{20}$ However, the concept of sustainable development is always problematic as the economic dimensions often tend to prevail in concerns about sustainability. In this paper, we attempt to address particularly the social and environmental sustainability aspects of building dams. As dams often produce large-scale adverse effects, it is vital to have mitigation strategies that can alleviate the worst impacts on local people, their livelihoods and the environment.

In this analysis, the Bui Dam in Ghana and the Kamchay Dam in Cambodia form the main basis of our discussion, with supplementary information from the Bakun Dam in Malaysia and the Zamfara Dam in Nigeria. The three dams

15 Bryant and Bailey 1997; Blaikie 1985; Tan-Mullins 2007.

16 Bryant 1992, 12.

17 Bryant 1997, 11; see also Peluso 1992; Bryant 1996.

18 Bryant and Bailey 1997.

19 Bury 2008.

$20 \mathrm{UN}$ and WCED 1987. 
in Cambodia, Malaysia and Ghana were completed and operationalized, whereas the dam in Nigeria was never constructed following reconnaissance surveys and feasibility studies. We conducted 68 interviews with members of the affected communities, and 82 interviews with policymakers, dam building companies, dam financiers, experts, non-governmental agencies and international agencies, in addition to examining the data from 40 focus groups and 149 household surveys in these four countries and China. We also undertook multi-level stakeholder mapping in order to identify the key stakeholders engaged in Chinese overseas hydropower projects in Cambodia, Ghana, Malaysia and Nigeria, as well as to gain a better understanding of the Chinese stakeholder landscape. We used the Net-Mapping Approach for the stakeholder analysis in order to determine key stakeholders, direct and indirect links to other stakeholders, and power relations. ${ }^{21}$

In addition to this qualitative primary information, we used quantitative secondary data from International Rivers' extensive database, which includes comprehensive up-to-date data about each of China's hydropower projects worldwide (for example, contractor, developer, financier, costs, size, location, environmental and social implications). We compiled secondary data to assess the environmental impacts of dams and their governance implications by examining the EIA reports of the dams. We also analysed dam project documentation and firms' strategies, such as Sinohydro's environmental and social strategies. We analysed the qualitative data by categorizing and coding the sources as a means of comparing and contrasting interpretations of events. ${ }^{22}$ We used the Nvivo 10 software to analyse the interview and focus group consultation data. These were analysed using narrative analysis rather than conventional "code and retrieve" methods since the former allows for more layers of embodied meaning to be revealed by including narrative style. ${ }^{23}$ This approach allowed us to compare several cases and draw parallels from similar findings and flag up any differences. ${ }^{24}$ The next sections will present the results and analysis.

\section{The Motives of Various Actors}

There are many actors involved in a Chinese overseas hydropower project cycle, and they have varying amounts of power vis-à-vis other actors within this industry and beyond, as illustrated in Figure 1. The lines in the figure represent the different flows of resources while the size of the symbols illustrates the power of the stakeholder. Among the ministries, the State Council and Political Bureau are perceived to be the most powerful actors, while the Export-Import Bank of China (ExIm Bank) is the most dominant actor in terms of financial flow. The stakeholder mapping of Chinese hydropower shows ten stakeholder groups and 


\section{Figure 1: Stakeholder Mapping of Chinese Hydropower Sector}

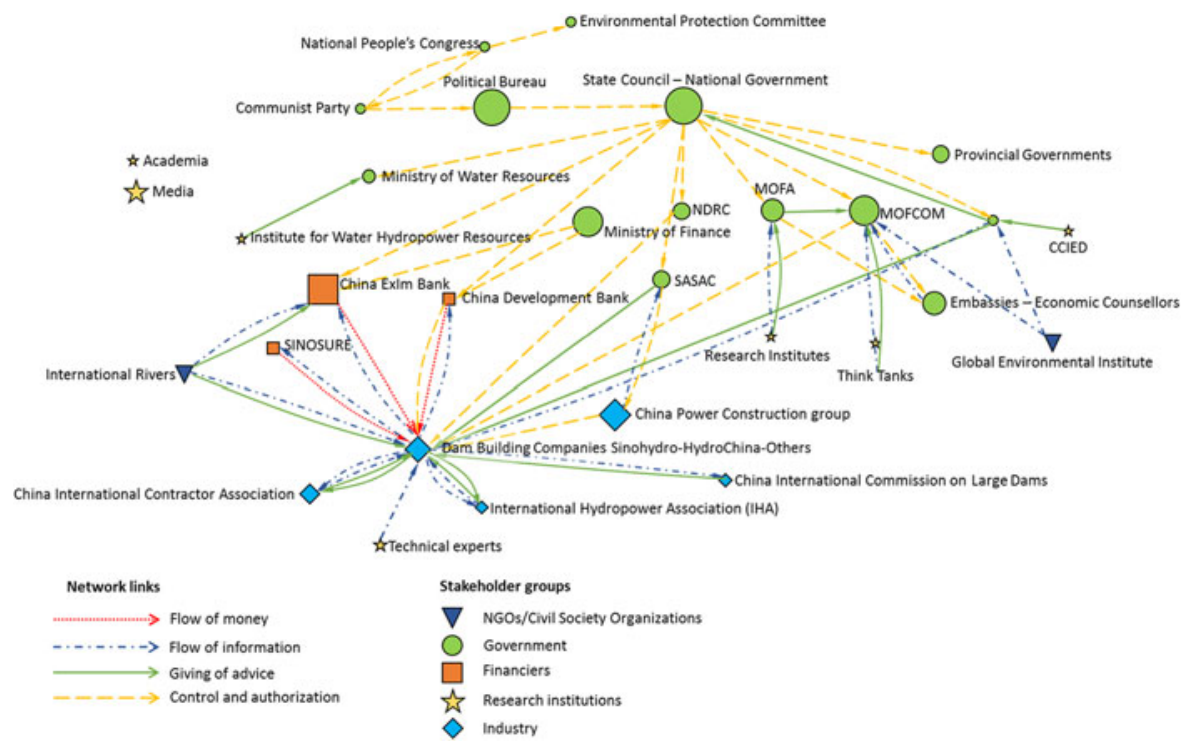

28 actors, which include financiers, contractors, operators, government agencies and local NGOs. Dam builders are excluded for reasons elaborated on in the following paragraphs.

There are numerous Chinese dam builders, and the companies registered and operating in China can vary from those subsidiaries specifically set up for overseas operation. These actors are usually the ones with the most power to effect physical changes on the environment, ${ }^{25}$ and subsequently on the livelihood options and power relations of the stakeholders at the local level. There are approximately 12 main builders, the biggest of which are Sinohydro, PowerChina Resources Limited (which is an international subsidiary of Sinohydro), China Huaneng Group, China Huadian Corporation, and the China Three Gorges Corporation. There are also many small players in the industry, such as suppliers and grid operators like Dongfang and China State Grid. Chinese dam financiers include firms such as ExIm Bank, Chinese Development Bank (CDB), Sinosure, and to a lesser extent, commercial/or nonpolicy banks, Industrial and Commercial Bank of China (ICBC) and the Bank of China (BoC). ${ }^{26}$

In interviews, many of the companies indicated that besides profits, the factors driving them to invest overseas included the "going out" policy, stiff competition within China, sector reforms, the declining number of suitable sites for new dams in China, and the lack of international competitors. Low costs, access to large 
finance and at times cheap loans (necessary for large infrastructural projects), and a big portfolio of domestic projects also make them attractive partners for clients around the world. ${ }^{27}$ According to one interviewee: "Big dam building is an important part of the 'going out' strategy, but I think it is just business; it has no strong relationship with political issues. On the one hand, there is market demand; on the other hand, China has rich experience of building dams. The domestic capacity in China is over supplied, so Chinese dam firms need to go global." 28 The "going out" policy was officially introduced in 2001 in China's Tenth Five-Year Plan (2001-2005), and was aimed at raising the rate of outflow foreign direct investment (FDI). It was comprehensively implemented in the 11th Five-Year Plan, which was drafted in $2006 .{ }^{29}$ A key aspect of this strategy is the undertaking of overseas contracts, especially infrastructure projects like roads, dams and telecommunications, all of which benefit the hydropower sector greatly.

There is intense competition among Chinese dam builders. ${ }^{30}$ First, as indicated above, there are over 12 major companies in a highly skilled and capital-intensive sector, many of which are state-owned enterprises (SOEs). In the past, it was possible to undertake projects that provided minimal profits, as national policy guidelines overrode profit concerns. In recent years, however, the number of overseas projects has become one of the key assessment criteria for leadership performance evaluations, and consequently such projects have been driven by senior executives seeking to maintain their status amid government SOE restructuring initiatives. ${ }^{31}$ Companies have also begun to look for ways to improve their profit margins and increase revenues by investing in the global market and cutting costs. Sector reforms in 2003, which involved privatizing five of China's largest power companies, placed companies in a better position to capitalize on their competitive advantages, function independently from central government directives and focus on profit-making. ${ }^{32}$ With fewer suitable sites for new mega dams in China, these companies recognize the need to explore external markets. As such, many firms, with little or no international market experience, have been compelled to explore new regions in the global hydropower industry such as Africa and Latin America. This has also meant that they are "confronted with challenges and responsibilities unfamiliar to them in China." 33

The lack of competition in the international market in both the construction and financing sectors is another pull factor for Chinese companies. Chinese construction firms have interests in as many as 350 dams in 74 countries, and Sinohydro,

27 Bosshard 2010

28 Interview with ExIm Bank, Beijing, August 2013.

29 CCPIT (China Council for the Promotion of International Trade). 2010. www.ccpit.org. Accessed 2 March 2016.

30 Interview with representative from Three Gorges Dam, Malaysia, July 2014.

31 Interview with representative from Sinohydro, Malaysia, July 2014.

32 McDonald, Bosshard and Brewer 2009.

33 International Rivers 2012, 6. 
an SOE engineering and construction company with a registered capital of 4 billion yuan, is a huge player in the hydropower industry. The reasons that there are so few global dam builders include the huge investment costs required to get projects to the construction stage, the negative opinions surrounding mega dam projects in terms of social and environmental impacts, and the high cost of compliance with social and environmental mitigation strategies required for such projects. ${ }^{34}$ As such, there is a huge gap in the market for the Chinese dam builders to fill. Furthermore, Chinese government funding for many of these projects comes with the conditionality that Chinese firms are contracted to build them.

Many Chinese hydropower companies are SOEs, and as mentioned above, although profit margin is one the main concerns for transnational companies, business decisions are sometimes made regardless of whether there will be positive returns. Likewise, some profitable dam proposals are halted owing to political reasons. This is because some of the projects are politically influenced, initiated and guaranteed by the Chinese government and, at times, aided by preferential loans. According to a Forbes report in 2015, 65 per cent of Chinese foreign direct investments make a loss, which is 15 per cent more than the 50 per cent global norm. ${ }^{35}$ An informant from a hydropower company also confirmed that "there are some obvious risks associated with some projects, but our business decisions are at times influenced by the government directives and the go-ahead is announced despite reservations from our company's senior management." 36

Several Chinese ministries are involved to various extents in the project cycle of an overseas Chinese dam venture. They include the State Council, the Ministry of Commerce (MOFCOM), the Ministry of Foreign Affairs (MOFA), the National Development and Reform Commission (NDRC), the Ministry of Environmental Protection (MEP), and the State-owned Assets Supervision and Administration Commission (SASAC) ${ }^{37}$ Although there are some provincial and municipal agencies involved in overseas dam building, they are not covered in this paper, as the overseas dam projects discussed here are of a size and scope that they require the approval of Chinese government agencies at the national level. Every project that is greater than US\$2 billion requires approval from the State Council, endorsement by the NDRC and MOFCOM approval as part of the 12th Five-Year Plan reforms. ${ }^{38}$ Furthermore, the State Council is the most powerful actor in the Chinese government and the overarching agency that oversees MOFCOM and the NDRC, the two most important stakeholders in the approval and supervision of overseas dam projects. MOFCOM is the main institute that approves and manages the overseas investments by SOEs, which includes hydropower dams. The NDRC approves smaller projects (less than US\$2 billion) and regulates overseas investments. The MOFA then provides

34 Interview with representative from an embassy, Ghana, September 2013.

35 Sautman and Yan 2015.

36 Interview with representative from a Chinese hydropower company, Cambodia, October 2013.

37 Urban et al. 2013.

38 Ibid 
advice on Chinese foreign policy, such as aid matters, while the MEP advises on environmental protection issues such as the EIA. Finally, SASAC assesses the performance of the SOEs. ${ }^{39}$ As indicated above, although some of the decisions are driven more by policies than revenue, we should not overestimate the power of these ministries over the companies. The Chinese government could and does influence these companies if there is a strategic case for doing so. Otherwise, these companies are generally not under the control of the national government and, in terms of decision making, are governed by boards and private investors.

One interesting aspect of the Chinese hydropower industry is that the financiers of these overseas projects tend to be Chinese state-owned banks such as the ExIm Bank and the CDB. In the past, concessional loans formed the majority of Chinese government aid to foreign countries. Today, most of the loans are at commercial rates. One major financial factor is China's willingness to lend to large, sometimes controversial, infrastructure projects when no one else will. The ExIm Bank, an export credit agency, is the most powerful creditor among the Chinese banks and funds the majority of China's overseas dams, including the Merowe Dam in Sudan, the Bui Dam, and the Kamchay Dam. Similar to the dam construction companies, most of these banks are SOEs and some of their decision making is influenced by Chinese government directives. However, the main criterion of making a profit still dominates when it comes to disbursing the loan. These Chinese banks usually conduct a risk assessment to address bad loan concerns. Many of these banks see political instability or leadership change as the biggest risk. For example, a representative from the ExIm Bank indicated that "political stability is at the top of the risk assessment followed by environmental and legal risk." 40 In addition, they also prefer to finance Engineering Procurement and Construction (EPC) projects rather than Build, Operate and Transfer (BOT) and Private-Public Partnership (PPP) projects, as the latter two are considered too risky, as we discuss next.

\section{Different Modalities and Processes}

The fluid power relations between different actors involved in the Chinese hydropower sector are best understood through an examination of the procedures involved in a mega dam project, from the opening negotiations to completion. Large scale infrastructure projects are usually initiated by the government of the host country and can be negotiated directly with a builder, or else they can be negotiated between the Chinese and host governments and then later opened up for bids. ${ }^{41}$ For example, Sinohydro negotiated the Bui Dam in Ghana right from the beginning, but only became the developer for the Kamchay Dam after the deal was agreed between the two governments. If a project requires

39 International Rivers 2012.

40 Interview with China ExIm Bank, Beijing, August 2013.

41 Interview with representative from a Chinese hydropower company, Malaysia, July 2013. 
funding from Chinese financiers, the economic counsellor office of the host country's embassy in China and the domestic industry association then jointly provide a letter of support. With this backing, the Chinese builder (if already in the process) then negotiates with bank and credit insurance companies for loans. The bank then submits the financing schedule first to the Chinese MOFCOM and then to the insurance companies for approval. The loan amount will only be finalized after the on-site assessment reports are evaluated and the approval procedures of the host country completed, which varies from country to country. ${ }^{42}$ This means the power largely lies in the hands of the builders and the host governments, as the Chinese government and financiers have very little say in the terms and conditions of the contracts and are only involved after the developer has been decided.

There are several contract types, for example BOT, EPC and PPP as well as other smaller types of contracts such as contracting and project management. The first three types have both advantages and disadvantages. At times, the power relations between the Chinese actors within the dam industry and the local/host partners and stakeholders are determined by the project type. EPC projects, also known as turnkey contracts, mean that the builder is contracted by a national developer and has complete responsibility for constructing the project in its entirety, from beginning to completion. EPC contracts have a lower financial risk (as they are with a contractor and not an investor) but carry a higher cancellation risk, as local partners could pull out if there are any issues. Sinohydro prefers EPC contracts as they reduce its risks by lowering its financial investment in the projects. For example, the Bui Dam is an EPC project funded by ExIm Bank. After the dam was constructed, it was handed over to the host government, which set up the Bui Power Authority to operate and manage the dam and its impacts, including the resettlement of local people and compensation. This project type also means the Chinese contractors tend to have very little engagement with local stakeholders or communities, as risks such as local opposition are usually left to the national developer or government agencies and not dealt with by the contractor. ${ }^{43}$ However, this does not mean that the contractor has no power over these communities; the construction of large dams alters the environment drastically in terms of water provision and livelihood options. This affects the communities' abilities to make decisions about their lives and livelihoods and their power vis-à-vis these development actors to varying degrees. This is different for many non-Chinese contractors, who consider issues such as involuntary resettlement, compensation and the environmental impacts of the dam as a result of their work, and may therefore be more proactive about such matters.

A BOT contract means the dam-building company will build and have ownership of the dam for a certain period of time, after which the dam will be handed over to the local government. Many banks and builders prefer this type of 
contract as there is less risk in terms of repayment; the builders will be able to recuperate the cost in years to come and it is more profitable in the long run. The Kamchay Dam, built by Sinohydro, is an example of a BOT contract. According to Sinohydro, Cambodia presents higher risks in terms of both political and operational issues. ${ }^{44}$ The latter is owing to the low quantity of water resources that can be used for power generation as there is an extended dry season in the country. This means the dam can only effectively run for six to seven months per year. To mitigate the risk of non-repayment, a law was passed by the Cambodian government that promises to bail out the company if such circumstances arise. In addition, the period of BOT ownership, usually 25-30 years, was extended to 44 years to make the investment more worthwhile, and so the project went ahead.

The BOT model gives the builders a lot more power in terms of ensuring (or reducing) the sustainability of these mega projects, as they are in full control (or denial) of the mitigation strategies and other sustainability issues of the dam in the long term. Despite this, the Chinese embassy in Phnom Penh pointed out that "BOT means an investment, it is purely economic and profit-driven based. It is not an aid project ... It is difficult for the embassy or ExIm Bank or others to interfere as this is purely an economic investment." 45 Yet, there may be the motivation and a responsibility (often legal) for the company to do more in terms of environmental protection and community development as they are present for a longer period. ${ }^{46}$ What is important with this model is that it may provide a negotiation space between the Chinese builders and the local communities. In theory, this allows a shifting of power between the builders and the local communities and civil society in terms of mitigation strategies and resettlement processes, which could have a positive outcome in terms of impact mitigation and ensuring the sustainability of the project. For example, Sinohydro claim that at the Kamchay Dam, following negotiations between the company and the Kamchay governor on behalf of the local community, the company permitted the local bamboo collectors, who weave the canes into baskets for a living, to access part of the private land that now belongs to Sinohydro to harvest bamboo. However, local villagers also have complained that they are experiencing severe hardship and loss of income owing to the flooding of the old bamboo area for the reservoir. Moreover, Sinohydro frequently closes the new bamboo area, which is also very far away, for extended periods of time. ${ }^{47}$ The local government also complained about contractual issues with Sinohydro as it is still waiting for payments to be made for environmental mitigation such as afforestation. ${ }^{48}$ BOT contracts can lead to a wider range of

44 Interview with Sinohydro, Cambodia, 18 October 2013.

45 Interview with representative of the PRC embassy, Cambodia, 2013.

46 "Chinese dam builders going overseas," http://www.internationalrivers.org/campaigns/chinese-dambuilders. Accessed 29 February 2016

47 Interviews with local community, Cambodia, May 2014.

48 Interviews with government officials, Cambodia, September 2014. 
corporate behaviour, from close cooperation between dam builders and local/ national institutions to address the adverse effects of large dams to dam builders leaving the management of the dam and its impacts completely to local/national institutions.

The PPP contract is currently the model preferred by local host and Chinese governments, as it gives ownership of the project to the builder and the host country's partners. It is viewed as the least risky type of contract as it requires commitment from all parties, and is also seen as the most feasible in terms of mitigating social and environmental implications owing to the long-term ownership and involvement of all relevant parties. ${ }^{49}$ The Chinese central government has also recently promoted PPP by awarding domestic PPP projects worth 3-8 million yuan each. ${ }^{50}$ However, this is the least preferred model for some dam builders for the very the same reasons; they view long-term commitment as high risk, especially if the country is not politically stable. With regard to contracting and project management, the Chinese builders are footloose in terms of their embeddedness in the local context and communities. They have very little ownership or commitment to the local communities and their roles are very constrained because of the short amount of time they spend in the project location. The Bakun Dam is a good example of a Chinese dam builder, Sinohydro, being a contractor for a dam construction project. Sinohydro was engaged at a later stage of the process to build part of the dam. The firm's job is to construct the relevant component and leave immediately. Although it has no obligations regarding social and environmental compliance, it does discuss matters such as construction compliance and labour issues with the local government agencies. Our interviews indicate that when Sinohydro is unfamiliar with the local regulatory framework, it usually engages local employees to overcome any issues. ${ }^{51}$ However, as its role is confined to the job specification, it has little or no power over the resettlement of the affected communities and rehabilitation of the immediate vicinity.

The above discussion demonstrates how power is manifest in different actors according to their varying abilities to engage with local stakeholders and their different roles and responsibilities in the project which in turn impact the sustainability of these hydropower projects. However, both the degree of sustainability of a hydropower project and the ability of Chinese transnational companies (TNCs) to impact on the physical environment through their investments and to affect communities in sovereign spaces beyond their home country call for a systematic understanding of how they operate and implement mitigation strategies such as CSR. May Tan-Mullins and Giles Mohan have also argued that in order to understand how Chinese companies operate in overseas

49 Interview with dam builder, Beijing, 8 May 2015.

50 "China to replace subsidy with reward to underpin PPP projects," The China Daily, 17 December 2015, http://www.chinadaily.com.cn/business/2015-12/17/content_22733729.htm. Accessed 2 March 2016.

51 Interview with representative from a Chinese hydropower company, Malaysia, July 2013. 
contexts, we need to look at the home country's regulatory and impact mitigation norms, to which we will now turn. ${ }^{52}$

\section{The Risk Mitigation Process}

In China, Chinese companies are legally bound by environmental regulations such as the project-based EIA mechanism and the national environment monitoring network along with more than 200 environmental policies, laws and regulations. ${ }^{53}$ In addition, SASAC has also called for SOEs to not only develop in a peoplecentred, "scientific" way and make profits but also to take responsibility for all stakeholders and the environment, and ultimately to harmonize the enterprise with social and environmental development. ${ }^{54}$ In 2008, the State Council also issued the Administrative Regulation on Contracting Foreign Projects. This was supplemented with guidelines on foreign investment and cooperation including the "Nine principles of the State Council on encouraging and regulating China's outbound investment." In particular, MOFCOM and the MEP issued "Guidelines on environmental protection in overseas investment and cooperation" in $2013 .{ }^{55}$

However, the Chinese government's push for social and environmental compliance from the TNCs is confined to vague and broad legislative requirements spread over a cross section of foreign investment laws and optional guidelines which have no means of enforcement or follow through. ${ }^{56}$ The situation is further exacerbated when firms carry out projects overseas as the Chinese government does not regulate activities beyond its borders: to enforce PRC laws on Chinese firms acting in another country would be an infringement of the other country's national sovereignty. However, the Chinese government has made it clear through public announcements that Chinese companies must abide by local laws, as it does not want China's reputation and soft power tarnished by the unlawful behaviour of Chinese companies. When Chinese firms carry out projects in Asia and Africa, they have to abide by the local regulations of the host countries. ${ }^{42}$ Our fieldwork indicates that Chinese dam builders usually attempt to adhere to the social and environmental policies and guidelines of the host country, in so far as they exist. In the absence of such policies and guidelines, Chinese dam builders will usually attempt to follow China's domestic policies and guidelines. The national host context therefore determines the quality of the impact mitigation of large dams. ${ }^{57}$ However, according to our interviewees, many of these guidelines are not enforced, are very general and need to be more sector specific. ${ }^{58}$

52 Tan-Mullins and Mohan 2013.

53 Fu et al. 2007.

54 SASAC 2008.

55 MOFCOM, SASAC and UNDP 2015.

$56 \mathrm{Ni}$, Sarkis and Zhu 2011.

57 Urban et al. 2015a; 2015b.

58 Interview with an embassy representative in Malaysia, July 2013; interview with a representative from an embassy in Cambodia, October 2013. 
SOEs such as Sinohydro also have comprehensive CSR programmes published on their websites. Sinohydro indicates on its website that it is committed to integrating social and environmental aspects in its tender submissions, in addition to the World Bank's safeguard policy. The company also published its ethical principles and sustainable policy online in 2014. ${ }^{59}$ Johan Nordensvärd and Frauke Urban note that these policies were similar to the World Bank standards in 2011, but were then replaced by weaker policies in 2013 and 2014 after Sinohydro was restructured. ${ }^{60}$ The restructuring involved splitting up the company into Sinohydro Resources and Sinohydro International, while PowerChina was created as a parent company owned by SASAC. In addition, Sinohydro was proud to obtain the ISO14001, an international standard for operations and environmental protection issued by the International Organization for Standardization (ISO). But, there is little mention of CSR activities in their overseas operations. Moreover, most of the activities organized in the names of CSR are philanthropic acts. For example, Sinohydro considered helping the local village schools in Malaysia, ${ }^{61}$ and donations for disaster relief and training local people in Cambodia are regarded as CSR initiatives. ${ }^{62}$ Yet, these are positive examples of Chinese overseas firms; many Chinese dam builders have no environmental and social policies in place.

As discussed above, given that much of the financing for SOEs comes from China's development banks, it is significant that in 2007 China started requiring commercial banks to review and weigh each applicant's environmental history before approving credit applications. ${ }^{63}$ Particularly, the MEP, with the China Banking Regulatory Commission, established a "green credit system," which aims to restrict the availability of credit to companies that violate environmental laws. ${ }^{64}$ This was endorsed by the China ExIm Bank, which adopted an environmental policy in 2004. More specific guidelines on social and environmental impact assessment were also added in 2007. The China Banking Regulatory Commission also launched the Green Credit Policy in 2012. However, the protocol requires projects to comply with host country policies - but not international standards - regarding environmental assessment, resettlement and consultation. ${ }^{65}$ This has major implications in the African continent as most of the EPC loans there were disbursed by the China ExIm Bank without serious examination of the environmental and social implications of these new projects. ${ }^{66}$

However, this has changed recently. Merowe Dam, according to some Chinese financiers, is an important turning point in the awareness of the greater

59 Sinohydro. 2014. http://eng.sinohydro.com/index.php?m=content\&c=index\&a=lists\&catid=9. Accessed 17 March 2016.

60 Nordensvärd and Urban 2015.

61 Interview with Sinohydro, Malaysia, July 2013.

62 Interview with Sinohydro, Cambodia, Oct 2013.

63 Chan-Fishel and Lawson 2007.

$64 \mathrm{Bu}$ et al. 2009.

65 Bosshard 2008.

66 Moss and Rose 2006. 
implications of Chinese hydropower dams. According to an informant from the China ExIm Bank, "we could not close our eyes to the impacts anymore," and as a result it has imposed stricter evaluation procedures regarding the social and environmental impacts of overseas projects. ${ }^{67}$ This move was also compelled by stricter environmental laws in China coupled with international pressure at the local level (in China and host countries) and international civil society and media.

What is interesting is that even within the same company there are different standards of compliance owing to the maturities of the company's subsidiaries and divisions and their varying degrees of awareness. For example, bureaus 8 and 14 of Sinohydro have better records of compliance because they have had more international exposure and experience. ${ }^{68}$ In conjunction to the above, the type of project (for example, BOT or EPC) has an impact on the compliance and risk mitigation strategies of these companies. We will now use the next few paragraphs to compare and contrast Sinohydro's EPC experience with the Bui Dam (Bureau 8) in Ghana and its BOT experience with the Kamchay Dam in Cambodia (managed by PowerChina Resources and Bureau 8) in order to illustrate the different risk mitigation strategies of the same company.

Built by Sinohydro, the Bui Dam is an EPC contract, the majority of funding for which came from the ExIm Bank. The dam should bring $400 \mathrm{MW}$ of electricity to Ghana's struggling power grid and allow some electricity exports to West African neighbours. The local partner in this project is the Bui Power Authority (BPA), whose role it is to monitor the delivery of the contract and manage resettlement during construction. Thus, the BPA has its own engineers and agents to report on quality and progress as well as health, safety and environmental standards. The BPA is also responsible for the forced resettlement of several thousand local people and their compensation payments.

One of the most contentious issues surrounding the Bui Dam is its environmental mitigation strategy. There is a huge gap between the project's EIA recommendations and their implementation. The Bui Dam's EIA had been conducted for a previous potential investor. Claire Sutcliffe assessed the dam's compliance with the EIA recommendations and found that many of the criteria, such as consultation with the local people, health and livelihood security and adequate compensation, were blatantly ignored. ${ }^{69}$ However, as the EIA had been undertaken before the deal with Sinohydro was fully negotiated, no reference was made to Sinohydro. This could also be attributed to the fact that Sinohydro was not involved in any of the planning processes (EIA, resettlement and dam design) prior to the construction of the project. This is because it is an EPC project and the power to mitigate the risks and outcomes lay in the hands of the local owners, the BPA. As such, it is difficult to ensure that those charged with the implementation and construction of such a

67 Interview with Chinese bank representative, Beijing, August 2013.

68 Interview with Sinohydro, Beijing, September 2013.

69 Sutcliffe 2009; Hensengerth 2013; Kirchherr, Disselhoff and Charles 2016. 
project own up to the social and environmental responsibilities that come with it. Furthermore, the low standing of the Ghanaian regulatory authorities in this sector makes rigorous environmental supervision difficult and leaves room for speculation as to how closely Sinohydro is adhering to the environmental conditions.

The Kamchay Dam is Cambodia's first large hydropower dam, with an installed capacity of 194 MW. The Kamchay deal was strongly supported and driven forward by the Cambodian prime minister himself, Hun Sen, to alleviate energy poverty, increase energy security and power economic growth. The Kamchay Dam is also the first in a series of dams to be financed and built by Chinese dam builders in Cambodia, and was financed by the China ExIm Bank and built by Sinohydro.

The Kamchay Dam has had a severe impact on the local population. Although there are no resettled communities from the area as the dam is located in Bokor National Park, there are approximately 22,000 people living in the rural area who have been affected by the dam. ${ }^{70}$ Four groups of people in particular have borne the brunt of the changes: the bamboo collectors, firewood collectors, fruit sellers and durian farmers. Environmental impacts were particularly apparent during the dam's construction, the most obvious being the flooding of 2,291 hectares of forest in the national park $^{71}$ which was previously used by the local communities for the collection of non-timber forest products such as bamboo. ${ }^{72}$ The dam has also hurt fish stocks and it is estimated that the migration patterns of at least 15 fish species, including threatened species, have been severely disturbed.

There have been serious shortcomings with regards to the Environmental and Social Impacts Assessment (ESIA). Under Cambodian law, development projects such as dams are required to have an EIA in place and approved before the construction process begins. Cambodian law also prescribes that the EIA process should be transparent, all decision making should be accountable, and a wide consultation process should involve affected local communities and civil society organizations. ${ }^{73}$ However, the Kamchay Dam's EIA process was flawed. It started late and the final EIA approval was in fact granted seven months after the inauguration of the dam. ${ }^{74}$ An NGO representative reported that "The main concern was that the Kamchay Dam was constructed before the approval of the EIA report. Therefore, the dam was constructed without having cleared EIA and [with] no Environmental Management Plan."75

Although there was a consultation process, according to one source, the "EIA consultation process was very rushed. The document was given to the consulted agencies on the Friday afternoon for a meeting on Monday morning. It is extremely difficult to read and assess the document as it is usually a couple of

70 NGO Forum Cambodia 2013.

71 SAWAC. 2011. http://www.sawac.co.za/articles.htm. Accessed 18 March 2016.

72 Urban et al. 2015a; $2015 \mathrm{~b}$.

73 Urban et al. 2015b; Middleton 2008; NGO Forum 2013.

74 Urban et al. 2015b; NGO Forum 2013.

75 Interview with an NGO representative, Cambodia, May 2014. 
hundred pages long."76 The consultation process prior to the dam's construction was patchy and ad hoc with little local participation, as our fieldwork and other reports confirm. ${ }^{77}$ Even today, several years into the operation of the dam, no English version of the ESIA report is available and the Cambodian version is only available to certain parties upon formal request to the Ministry of the Environment. It has been reported by several experts that the content of the ESIA is of poor quality. For example, the ESIA does not assess the impact of the dam on species and habitats and merely lists which species live in the national park. ${ }^{78}$ Overall, the implementation of environmental and social safeguards was minimal and not in line with Cambodian legislation. In addition, the Environmental Management Plan, which aims to implement mitigation measures to reduce the negative effects of the dam, was not put in place until the final stages of the dam's construction.

Theoretically, as the Kamchay Dam is a BOT project, the builder (Sinohydro) should be more engaged with the local stakeholders in terms of consultation and mitigation strategies as there is a greater need to ensure the sustainability of this project in order to recoup the investment. And, indeed, there was consultation with local stakeholders with regards to the EIA reports, as demonstrated earlier. However, our fieldwork has found that the EIA is often just a rubber-stamping exercise; it can be conducted in a very rushed manner, sometimes using generic texts, and often lacks any proper meaningful consultation with the other stakeholders such as the local community and civil society. Indeed, the usual complaints of non-compliance, as illustrated above, usually centre upon matters such as the lack of transparency, the poor dissemination of information to the public and the inadequate implementation of the EIA. ${ }^{79}$ If there is any consultation process at all, it usually involves low-ranking officials with no real power to make or implement any changes. In addition, many locals are not consulted and public participation therefore exists only on paper rather than in practice.

From our case studies, we found that major BOT companies are committed to following international standards but seldom implement them. This may be owing to the lack of manpower, willing or skillsets of the local project managers at the site, which may be at odds with the ambitions of the company heads. PowerChina Resources and Datang have both committed to World Bank safeguarding policies, and Datang, Huadian and Huaneng have signed up to the United Nations Global Compact, although performance in the field remains patchy. ${ }^{80}$ Chinese companies have strong commitments to EMP and EIA but have big policy gaps in downstream flow, transboundary impacts, community relations and labour management, as our case studies show. Weak performance on the ground could be owing to many factors such as poor training, unfamiliarity

79 Interview with an ambassador and NGO representative, Cambodia, May 2013.

80 See https://www.unglobalcompact.org/ for information on the UN Global Compact. 
with the local context, language barriers, a lack of contacts, different modalities determining the interaction with local communities, and an incomplete understanding of the challenges local communities face because of the dam's construction. For example, Sinohydro is said to have set aside a so far untouched budget of US\$5 million for implementing mitigating measures such as afforestation; however, even high-ranking officials at the provincial department for the environment and the EIA office are criticizing Sinohydro for its inaction. When questioned about this fund, the representative from Sinohydro responded that, "We want to do a lot with this budget but we don't know where to start. It would be nice if we could work with the local government so they could tell us what is important and what to prioritize. But things are very slow moving, due to the language barriers and different working style." 81

Indeed, when Chinese SOEs enter new markets with complex environments of heterogeneous legal and social demands, they often do not make it clear which economic activities and practices can be considered legitimate and acceptable. ${ }^{82}$ Furthermore, there exists a vacuum of enforcement as local governance can be lax or non-existent, particularly in weak or failed states in Africa. In such cases, the enforcement of CSR programmes or social and environmental mitigation strategies falls exclusively upon corporate managers, who might not necessarily be trained in managing social, labour and environmental issues ${ }^{83}$ or perhaps might use Chinese guidelines as their standard ${ }^{84}$ Many companies hence depend on particular managers' experience to manage CSR issues, which leads to ad hoc and inconsistent responses. ${ }^{85}$ Hence, there exists a gap between formulation, implementation and enforcement of CSR regulations which can result in negative environmental and social implications. ${ }^{86}$ Moreover, away from the seat of control in Beijing, managers have more urgent issues at hand, such as how to overcome cultural and linguistic barriers at local and national levels, and hiring/managing local workforces. In addition, CSR policies tend to be determined mainly in company headquarters in China; there are no specialized departments or units in Africa and Asia managing CSR issues. Also, like many other non-binding governance mechanisms, it is ultimately the company's decision to implement CSR.

When comparing case studies, we found that, interestingly, EPC contractors generally outperformed BOT companies in social and environmental standards as many responsibilities are devolved to local partners (such as the Bui Power Authority), who are more embedded within the local communities and have a clearer understanding of local cultural and social norms and environmental conditions. However, if the sole responsibility for compliance and mitigation lies in the hands of the local owners/ partners, Chinese dam builders have no say in the

81 Interview with representative from Sinohydro Cambodia May 2013.

82 Scherer and Palazzo 2011.

83 Interview with a CSR practitioner, Beijing, 21 October 2011.

84 Scott 2012.

85 Zadek et al. 2009.

86 Mol 2011, 791. 
strategies used. Failure on the part of the local partners to manage or mitigate the risks properly can lead to local opposition to the project. Companies who compensated for their lack of local knowledge by employing local staff to deal with such issues also performed better in both types of contracts.

\section{Conclusion: Political Ecology of Chinese Hydropower Dams}

This paper explores what shapes the behaviour of Chinese stakeholders engaged in large hydropower projects in Asia and Africa. The recent slowdown in the Chinese economy has huge implications for the global economy and developing regions such as Africa and Asia. A reduction in Chinese trade and investments has meant that borrowing nations now face challenges in terms of debt repayment. This, however, does not mean that Chinese firms building dams will slow down globally. On the contrary, the recent establishment of the Asian Infrastructure Investment Bank, spearheaded by the Chinese and the BRICs bank, together with the "one belt one road" initiative, will see more initiatives and a stronger push for Chinese enterprises to go global. This means SOEs such as Sinohydro and Three Gorges will be bidding for more overseas infrastructure projects and more Chinese dams will be built in the global south.

Moreover, as hydropower dams are one of the largest energy infrastructures in the world and there is an enormous need to build more dams as part of the climate change mitigation strategy, we need to rethink how to minimize the adverse effects of large dams and improve the sustainability of the hydropower industry. Through a political ecology framework, this paper examines the power relations between the different Chinese stakeholders at various phases of the project cycle. From the decision making at the Chinese state level, to financing and subsequently the actual construction, we question where power lies and what empowers the actors. In cases like the Kamchay Dam, we find that Sinohydro has the most power to inscribe physical change on the environment and in turn affect the livelihoods of the surrounding communities, but it also has the greatest potential to effect positive change in terms of mitigation strategies for long-term improvements in the dam-building industry. For the Bui Dam, the power of the Chinese builders is diluted by their partnership with the Bui Power Authority, which has better knowledge of the local context and hence has the tools to mitigate the negative consequences of the project. By knowing which actor is most empowered at the different phases of the project, it is possible to engage with the appropriate actor and argue for better formulation and implementation of the mitigation strategies in the long run.

The model for cooperation between Chinese actors and local partners also plays a determining role in the outcome of the project. The PPP model is the preferred approach in terms of long-term ownership and social/environmental mitigation strategies. With more at stake for both the Chinese and local partners, the global enterprises are "locked in" for a longer period of time which allows for 
more integration with the local communities and also provides space for meaningful consultation and negotiation for the best mitigation strategies. It also gives the local government a stronger role. This in turn will affect the power relations between the global and the local actors, and sustainable development for both global enterprises and local communities.

Mitigation strategies play a big part in the sustainability of these Chinese hydropower dams, but most Chinese global companies still lag behind Western countries in terms of CSR and local implementation. From our four case studies, we have found that there is a need for Chinese dam builders to understand CSR as a collective mitigation strategy rather than mere philanthropy. Furthermore, it is necessary to engage with Chinese global enterprises on international principles such as the OECD guidelines for TNCs and responsible business conduct. MOFCOM has shown a willingness to investigate these options. The OECD recently held a special outreach session in Beijing to introduce the Chinese government to the OECD guidelines, ${ }^{87}$ and at a workshop the project team organized in 2015, Sinohydro mentioned its willingness to learn more about the International Hydropower Association's Sustainability Assessment Protocol, although to date, it has not taken any action to adopt it. The importance of due diligence for the whole supply chain and project cycle as a risk management strategy should be communicated to these global builders and local partners persistently. However, the Chinese companies' rhetoric in terms of CSR and mitigation strategies has changed, from using their lack of knowledge of governance and local laws to explain the gap to placing increasing emphasis on abiding and respecting local laws, culture and customs and showing an interest in international best practice.

This paper also shows that host governments in Asia and Africa are relatively lax on enforcement. Using the political ecology framework, we question what empowers an actor in the dam-building process. It could be resources, such as enforcement budgets, manpower, skills, and the knowledge and technology of local regulatory agencies. This problem is not exclusive to our four case studies but is evident in almost all developing regions and natural resource sectors. However, there is a proliferation of empowered stakeholders with access to media and technology who are able to make their voices heard in a global arena. Social media such as Facebook, Twitter and WeChat have become "engines of change" in this new age. As such, the checks and balances fall on to the lap of civil society. For example, there are commendable efforts by various international institutions and NGOs at the local and global level to socialize China into the global norms of compliance with social and environmental standards and best practices in mitigation strategies. The World Wildlife Fund has launched the Global Shift programme, which focuses on biodiversity and sustainable timber trade between China and Africa, while International Rivers is 
examining the ecological consequences of Chinese hydropower investments around the world. At the same time, an increasing number of non-state actors at the regional level in Africa, such as trade unions, civil society organizations, academics and scientists, are turning their attention to Chinese companies and their role in the exploitation of and low economic returns on environmental resources. ${ }^{88}$ For example, the African Labour Research Network investigated Chinese operations and their impacts on local communities and ecosystems. ${ }^{89}$ In particular, the work done by International Rivers in recent years on directly engaging Chinese hydropower companies in various initiatives such as the benchmarking exercise has had positive implications for knowledge exchange on best practices and has created a platform for conversation on these matters. ${ }^{90}$

Thus, it is with growing pressure from non-state stakeholders at the local, national, regional and global levels that changes to Chinese policy may be achieved. At the same time, there is an urgent need to create legislative and institutional frameworks to check Chinese investment in developing regions (within China and beyond) and particularly to address concerns with social and energy justice, environmental protection and rehabilitation, and transparency and accountability. Ultimately, creating an articulation and negotiation space for non-state actors, which was previously unavailable to them, will allow their opinions to be heard, meaningful consultation to be conducted and negotiation to take place regarding their immediate environmental concerns surrounding their livelihoods.

\section{Acknowledgement}

The authors gratefully acknowledge ESRC UK funding for this paper (ESRC reference ES/J01320X/1). They would also like to thank Giuseppina Siciliano and Yolanda Sheng for their assistance creating Figure 1.

\section{Biographical notes}

May Tan-Mullins is professor of international relations at the University of Nottingham Ningbo China. She is the dean of the Graduate School, director of the Institute of Asia and Pacific Studies and also series editor of the Palgrave Series in Asia and Pacific Studies. Her research interests include the political ecology of rising China, environmental and energy justice, and poverty alleviation and building resilience for the poorest and most vulnerable.

Frauke Urban is reader in environment and development at SOAS, University of London. She is the principle investigator of the ESRC-funded project, "China goes global: a comparative analysis of Chinese dams in Asia and Africa." Her

90 International Rivers 2015. 
research interests are the linkages between energy, climate change and international development.

Grace Mang is a water lawyer. She is currently the director of partnerships and community engagement at the Murray-Darling Basin Authority in Australia. Prior to this, she was the director of programmes at International Rivers in Beijing, China, where she developed an effective and innovative programme to address China's global role in hydropower development and the world's rivers.

\begin{abstract}
摘要：水电大坝项目近来因其满足低碳发电和可能减轻气候变化的偏好重 回聚光灯下。复兴大型水电项目的主角是作为国内和国外最大大坝建造者 的中国企业，它们在中低收入国家开拓出了许多项目机会。然而大型水电 大坝除带来潜在的发展性和减少碳排放的贡献外，还会伴随着巨大的经济 成本、深远的负面环境变化和社会影响。本文利用在加纳、尼日利亚、柬 埔寨和马来西亚的四个水电项目中收集到的田野数据将对参与亚非大型水 电项目中国利益相关方的行为进行评估。本文将先探明不同中国利益相关 方的利益点所在，然后再对这些中国企业建造的大坝在当地、国家层面和 国际层面产生的影响进行探究。本文结论为虽然水电大坝有助于在未来提 高能源安全水平和降低能源型贫困, 但项目的规划、建造和缓解策略需要 更多以可持续的思路考虑国家层面的发展重点、当地社群的需求及对自然 生态的影响。
\end{abstract}

关键词: 中国; 非洲; 亚洲; 水电; 发展; 社会环境

\title{
References
}

Ansar, Atif, Bent Flyvbjerg, Alexander Budzier and Daniel Lunn. 2014. "Should we build more large dams? The actual costs of hydropower megaproject development." Energy Policy 69, 43-56.

Baah, Anthony Yaw, and Herbert Jauch (eds.). 2009. Chinese Investments in Africa: A Labour Perspective. African Labour Research Network, http://www.cebri.org/midia/documentos/315.pdf.

Billington, David, and Donald Jackson. 2006. Big Dams of the New Deal Era: A Confluence of Engineering and Politics. Norman, OK: University of Oklahoma Press.

Blaikie, Piers. 1985. The Political Economy of Soil Erosion in Developing Countries. London: Longman.

Bosshard, Peter. 2008. "China's environmental footprint in Africa." China in Africa Policy Briefing 3, $1-12$.

Bosshard, Peter. 2010. "China's overseas dam builders: from rogue players to responsible actors?" Japan Focus 8(17), No. 2, http://www.japanfocus.org/-Peter-Bosshard/3347. Accessed 1 March 2016.

Bosshard, Peter. 2014. "China dialogue. Is the world's largest biggest dam builder willing to change?" 16 December, https://www.chinadialogue.net/blog/7605-Is-the-world-s-biggest-dam-builder-willingto-change-/en. Accessed 1 March 2016.

Brown, Philip, Desiree Tullos, Bryan Tilt, Darrin Magee and Aaron Wolf. 2009. "Modeling the costs and benefits of dam construction from a multidisciplinary perspective." Journal of Environmental Management 90(3), 3030-3311.

Bryant, Raymond. 1992. "Political ecology: an emerging research agenda in third world studies." Political Geography 11, 2-13. 
Bryant, Raymond. 1996. "The politics of forestry in Burma." In Philip Hirsch and Carol Warren (eds.), Politics and Environment in Southeast Asia: Resources and Resistance. London: Routledge, 107-121.

Bryant, Raymond. 1997. "Beyond the impasse: the power of political ecology in third world environment research.” Area 29(1), 5-19.

Bryant, Raymond, and Sinead Bailey. 1997. Third World Political Ecology. London: Routledge.

$\mathrm{Bu}$, Yongxiang, Zhu Hongmei, Wu Chaoming, Chen Yingmei and Wu Zhi. 2009. "Towards sustainable development: the role of China's financial sector." World Wildlife Fund for Nature and the People's Bank of China, http://d2ouvy59p0dg6k.cloudfront.net/downloads/pboc_report_en.pdf. Accessed 19 July 2016.

Bury, Jeffrey. 2008. "Transnational corporations and livelihood transformations in the Peruvian Andes: an actor-oriented political ecology." Human Organisation 67(3), 307-321.

Chan-Fishel, Michelle, and Roxanne Lawson. 2007. "Quid pro quo? China's investment for resource swaps in Africa." Development 50(3), 63-68.

Fu, Bojie, Xuliang Zhuang, Buibin Jiang, Jianbo Shi and Yihe Lu. 2007. Environmental Problems and Challenges in China. Beijing: Chinese Academy of Sciences.

Hensengerth, Oliver. 2013. "Chinese hydropower companies and environmental norms in countries of the global south: the involvement of Sinohydro in Ghana's Bui Dam." Environment, Development and Sustainability 15(2), 285-300.

Hensengerth, Oliver. 2015. "Global norms in domestic politics: environmental norm contestation in Cambodia's hydropower sector." The Pacific Review 28(4), 505-528.

International Rivers. 2012. The New Great Walls: A Guide to China's Overseas Dam Industry. Berkeley, CA: International Rivers.

International Rivers. 2015. Benchmarking the Environmental and Social Policies and Practices of International Hydropower Companies: Stage One: Chinese Overseas Hydropower Companies, Part One Methodology and Analysis. Beijing: International Rivers.

Kirchherr, Julian, Tim Disselhoff and Katrina Charles. 2016. "Safeguards, financing, and employment in Chinese infrastructure projects in Africa: the case of Ghana's Bui Dam." Waterlines 35 (1), http://dx.doi.org/10.3362/1756-3488.2016.005. Accessed 9 July 2016.

McDonald, Kristen, Peter Bosshard and Nicole Brewer. 2009. "Exporting dams: China's hydropower industry goes global.” Journal of Environmental Management 90, 294-302.

McDonald-Wilmsen, Brooke, and Michael Webber. 2010. "Dams and displacement: raising the standards and broadening the research agenda." Water Alternatives 3(2), 142-161.

Mertha, Andrew. 2008. China's Water Warriors: Citizen Action and Policy Change. New York: Cornell University Press.

Middleton, Carl. 2008. Cambodia's Hydropower Development and China's Involvement. Phnom Penh: Rivers Coalition Cambodia.

MOFCOM, SASAC and UNDP. 2015. 2015 Report on Sustainable Development of Chinese Enterprise Overseas: Chinese Academy of International Trade and Economic Cooperation. Beijing: Ministry of Commerce.

Mol, Arthur. 2011. "China's ascent and Africa's environment.” Global Environmental Change 21(3), 785-794.

Moss, Todd, and Sarah Rose. 2006. "China ExIm Bank and Africa: new lendings, new challenges." Centre for Global Development, http://www.eldis.org/vfile/upload/1/document/0708/DOC22802. pdf. Accessed 1 April 2016.

NGO Forum Cambodia. 2013. The Kamchay Hydropower Dam: An Assessment of the Dam's Impacts on Local Communities and the Environment. Phnom Penh: NGO Forum.

Ni, Na, Joseph Sarkis and Qinghua Zhu. 2011. "Wind of change: corporate social responsibility in China." Ivey Business Journal, January/February, http://iveybusinessjournal.com/publication/ winds-of-change-corporate-social-responsibility-in-china/. Accessed 2 March 2016.

Nordensvärd, Johan, and Frauke Urban. 2015. "The stuttering energy transition in Germany: wind energy policy and feed-in tariff lock-in.” Energy Policy 82, 156-165. 
OECD. 2015. "Workshop in China on responsible business conduct," 28 May, https://mneguidelines. oecd.org/china-rbc-workshop-2015.htm. Accessed 1 May 2016.

Peluso, Nancy. 1992. Rich Forest, Poor People: Resources Control and Resistance in Java. Berkeley, CA: University of California Press.

SASAC. 2008. "Guidelines to the state-owned enterprises directly under the central government on fulfilling corporate social responsibilities," http://www.bsr.org/reports/bsrchina/BSR_China-CSRGuidelines.pdf. Accessed 12 April 2012.

Sautman, Barry, and Yan Hairong. 2015. "Chinese neo-colonialism in Africa: a bien-pensant political ploy," The China Policy Institute Blog, 17 December, http://blogs.nottingham.ac.uk/ chinapolicyinstitute/2015/12/17/chinese-neo-colonialism-in-africa-a-bien-pensant-political-ploy/. Accessed 2 March 2016

Scherer, Andreas Georg, and Guido Palazzo. 2011. "The new political role of business in a globalized world: a review of a new perspective on CSR and its implications for the firm, governance, and democracy." Journal of Management Studies 48(4), 899-931.

Schiffer, Eva. 2007. The Power Mapping Tool: A Method for the Empirical Research of Power Relations. Washington, DC: International Food Policy Research Institute (IFPRI).

Scott, Douglas. 2012. "Do Chinese extraction (mining, oil and gas) activities in Africa overlap with areas of conservation value? Environmental perspectives on Chinese global engagement." African East-Asian Affairs - The China Monitor 68, 11-16.

Sovacool, Benjamin, and L.C. Bulan. 2011. "Behind an ambitious megaproject in Asia: the history and implications of the Bakun hydroelectric dam in Borneo." Energy Policy 39(9), 4842-59.

Sovacool, Benjamin, Daniel Nugent and Alex Gilbert. 2014. "Construction cost overruns and electricity infrastructure: an avoidable risk?” The Electricity Journal 27(4), 112-120.

Sutcliffe, Claire. 2009. "Interviews with people to be affected by Bui Dam: a field report." Unpublished paper.

Tan-Mullins, May. 2007. "The state and its agencies in coastal resources management: the political ecology of fisheries management in Pattani, southern Thailand.” Singapore Journal of Tropical Geography 28(3), 348-361.

Tan-Mullins, May, and Giles Mohan. 2013. "The potential of corporate environmental responsibility of Chinese state-owned enterprises in Africa." Environment, Development, Sustainability 15(2), 265-284.

UN and WCED. 1987. "Our common future: the Bruntland Report," https://en.wikipedia.org/wiki/ Our_Common_Future. 1. Accessed 9 February 2017

UNFCCC (United Nations Framework Convention on Climate Change). 2015. Adoption of the Paris Agreement. Paris: UNFCCC.

Urban, Frauke, Johan Nordensvärd, Deepika Khatri and Yu Wang. 2013. “An analysis of China's investment in the hydropower sector in the Greater Mekong Sub-Region." Environment, Development and Sustainability 15(2), 301-324.

Urban, Frauke, Giuseppina Siciliano, Kim Sour, Grace Mang, Pich Dara Lonn and May TanMullins. 2015a. "South-south technology transfer of low-carbon innovation: large Chinese hydropower dams in Cambodia." Sustainable Development 23, 232-244.

Urban, Frauke, Johan Nordensvärd, Giuseppina Siciliano and Binqin Li. 2015b. "Chinese overseas hydropower dams and social sustainability: the Bui Dam in Ghana and the Kamchay Dam in Cambodia." Asia \& the Pacific Policy Studies 2(3), 573-589.

Walker, Beth, and Liu Qin. 2015. "The hidden costs of China's shift to hydropower," The Diplomat, 29 July, http:/thediplomat.com/2015/07/the-hidden-costs-of-chinas-shift-to-hydropower/. Accessed 4 April 2016.

Wiles, Janine L., Mark W. Rosenberg and Robin A. Kearns. 2005. "Narrative analysis as a strategy for understanding interview talk in geographic research." Area 37(1), 89-99.

Wolcott, Harry. 1990. Writing Up Qualitative Research (Qualitative Research Methods). Newbury Park, CA: Sage Publications.

Wolf, Eric. 1972. “Ownership and political ecology.” Anthropological Quarterly 45(3), 201-205. 
488 The China Quarterly, 230, June 2017, pp. 464-488

World Commission on Dams. 2000. Dams and Development: A Report to the World Commission on Dams. London: Earthscan Publications.

Yin, Robert K. 2009. Case Study Research: Design and Methods. Newbury Park, CA: SAGE.

Zadek, Simon, Xiaohong Chen, Zhaoxi Li, Tao Jia, Yan Zhou, Kelly Yu and Maya Forstater. 2009. "Responsible business in Africa: Chinese business leaders' perspectives on performance and enhancement opportunities." Corporate Social Responsibility Initiative Working Paper No. 54, Harvard Kennedy School. 